\title{
OSTEOPROTEGERIN, SCLEROSTIN, AND OSTEOCALCIN SERUM LEVELS IN THYROID DISORDER PATIENTS
}

\author{
F. F. RIJA', S. Z. HUSSEIN $2 \bowtie$, M. A. ABDALLA ${ }^{3}$ \\ ${ }^{1}$ Department of Biology, Tikrit University - College of Sciences, Tikrit, Iraq; \\ ${ }^{2}$ Clinical Biochemistry Unit, Salah Aldeen Health Directorate, Tikrit, Iraq; \\ ${ }^{3}$ Department of Human Anatomy, Tikrit University College of Medicine, Tikrit, Iraq; \\ 凶e-mail: drmohammadahmad68@gmail.com
}

Received: 15 February 2021; Accepted: 22 September 2021

The maintenance of thyroid hormone homeostasis is essential in the regulation of skeletal system development, bone tissue mineralization and fracture risk prevention. This study was carried out to evaluate the serum level of osteoprotegerin (OPG), sclerostin (SOST), and osteocalcin (OC) in hypo- and hyperthyroidism patients. A total number of examined patients was 90 individuals, 30 of them were normal as a control group, the rest 60 individuals were arranged in two groups: 30 patients with hypothyroidism and 30 patients with hyperthyroidism. Serum assay tests for OPG, SOST, OC, thyroid stimulating hormone (TSH), total triiodothyronine (T3), and total thyroxine (T4) were used. The present study reported high levels of SOST, T3, and T4 and low levels of OPG, OC, and TSH in patients with hyperthyroidism compared to control. Whereas in patients with hypothyroidism only SOST and TSH levels were increased, but OPG, OC, T3, and T4 levels were low compared to control. The data obtained indicate the correlation on osteoprotegerin, sclerostin, and osteocalcin levels with thyroid hormones disturbances.

Ke y w o rd s: osteocalcin, osteoprotegerin, sclerostin, thyroid disorders.

$\mathrm{T}$ hyroid hormones play essential roles in skeletal system development, control of bone tissue mass, and bone turnover regulation. The maintenance of strength and optimum bone mineralization mainly depends upon the euthyroid status; therefore, hypo and hyperthyroidism patients are more susceptible to fracture risk [1].

The thyroid gland principally secretes $\mathrm{T} 4$ as a prohormone, but the active form is T3 which is produced in a very small amount. The main amount of serum T3 is formed via 5-deiodination to T4 by specific type 1 and 2 iodothyronine deiodinase enzymes (D1 and D2) [2].

Because of several changes in T3 actions on skeletal cells due to alteration in thyroid gland status, a profound effect on skeletal system development and maintenance of adult bone would be expected to occur. Thyroid stimulating hormone receptors (TSHR) deficiency in mice suggested that TSH is regarded as a direct inhibitor for bone turnover process through activation to TSHR which is expressed on both osteoblast and osteoclast cells [3].

In previous studies on adults, the thyroid dysfunction effect on bone turnover process and remodeling cycle had been reported. In hypothyroidism patients, a prolonged period for remodeling cycle due to two-fold extension in the time for osteoclastic resorption stage or phase, in addition to fourfold prolongation in osteoblastic bone tissues formation time with secondary bone tissue mineralization would be established. Those remarkable changes lead to decreased bone turnover process with total gaining in bone tissue mass and ultimate mineralization. On contrary, the bone formation and resorption processes are both obviously accelerated in patients with hyperthyroidism because the bone remodeling cycle duration is shortened due to decreased resorption phase about $60 \%$ and decreased formation phase about 30\%. A marked increment in the frequency of start over to bone remodeling cycle is recognized, in

(C) 2021 Rija F.F. et al. This is an open-access article distributed under the terms of the Creative Commons Attribution License, which permits unrestricted use, distribution, and reproduction in any medium, provided the original author and source are credited. 
association with a greater extent increment of bone resorption compared to bone formation. The final results for all mentioned changes are approximately $10 \%$ bone tissue loss in every single remodeling cycle that occurred in hyperthyroidism patients which ultimately leads to excessive bone turnover process and osteoporosis [4, 5].

Thyrotoxicosis or Graves' disease patients are undergoing all previous features due to persistent activity of TSHR on follicular cells of thyroid gland as a response to specific stimulating antibodies to TSHR [6].

Sclerostin (SOST) considers as a glycoprotein that is chiefly formed in osteocyte cells as a result of specific SOST gene activity causing a reduction in bone formation at osteoblast cells through inhibition of the Wnt signal pathway. Using wild type mice with non-mechanical load, exhibited a high SOST synthesis compared to low Wnt/ $\beta$-catenin signal pathway. Furthermore, even after decreasing the mechanical load, the bone tissue loss was not enough to be detected in those mice that were SOST negative [7].

SOST and thyroid hormones might influence the bone tissue development through the Wnt signal pathway so that it appeared logical to look for both in hyperthyroidism individuals. The association between thyroid hormones and SOST from one side; and the association of both with some bone metabolic biomarkers like serum osteocalcin (OC) and osteoprotegerin (OPG) for bone resorption, from the other side were investigated [8].

OPG with its specific cognate ligand that is known as receptor activator of nuclear factor-kappa ligand (RANKL), had been recognized as essential factors implicated in bone metabolism control intermediating paracrine signaling pathway between osteoblast and osteoclast cells [9]. OPG characterized by inhibition of interactivity occurred between RANKL with its particular receptor presented on the surface of osteoclast cell because it acting as decoy receptors that binding RANKL [10]. In human beings, OPG is involved in the pathogenesis process of women with postmenopausal osteoporosis and many other metabolic disturbances distinguished by bone tissue loss [11].

The physiological process of age-related increment in OPG formation is usually masked in hyperthyroidism patients. A preceding report exhibited that (1) hyperthyroidism clinical condition is mostly associated with high serum OPG level due to excessive production of thyroid hormone levels which ul- timately causing acceleration for bone turnover; (2) individuals with Graves' disease show higher serum OPG levels compared to individuals with toxic nodular goiter; and (3) the management of hyperthyroidism patients causes low serum OPG levels in temporal association with normalization status for bone metabolism [12].

Osteocalcin, which is mainly used as a boneproducing factor during the process of bone turnover is synthesized by osteoblast cells, stored at bone matrix substance, and maybe regularly released to the bloodstream. In cases of the excessive bone turnover process including women at postmenopausal period or hyperthyroidism individuals, high serum OC is reported. Hyperthyroidism considers as the most common medical example reflecting excessive bone turnover [13].

In this study, the aim was to evaluate the level of OPG, SOST, and OC in hypo- and hyperthyroidism patients.

\section{Materials and Methods}

Study design and patients. All thyroid disease and control subjects underwent to draw about 5-10 $\mathrm{ml}$ of a venous blood sample and allow it to get clotting in a plain tube. The serum was centrifuged at (3000 rpm) for $30 \mathrm{~min}$, aspirated and subdivided in aliquots of several plastic tubes, and then preserved at $\left(-20^{\circ} \mathrm{C}\right)$ until estimation time. A total sample of 90 individuals involved in this study, 30 of them were normal as a control group, while the rest 60 individuals were arranged in two categories (30 patients with hypothyroidism and another 30 patients with hyperthyroidism). All individuals who agreed to participate in this study, their age was ranging (18-50) year with age mean (32 \pm 5$)$ year. This study was carried out from April 2019 to October 2019 at Salah Aldeen General Hospital in Tikrit city.

Ethical statement. The above-mentioned sampling protocols were designed in concordance with World Medical Association Declaration of Helsinki, revised in 2000, Edinburgh. The Medical Ethics Committee of Tikrit University College of Medicine approved the study (IQ.TUCOM.REC.2019.112). All participants consented (in a written form) to be involved in this research and the collection of data was kept confidential and not be divulged except for the purpose of the study.

Laboratory, anthropometric and clinical data collection. All individuals were investigated for OPG, SOST, OC, TSH, Total T3, and Total T4 tests. 
All those control subjects were non-diabetic and non-smoker with neither a familial history of diabetes mellitus nor a personal history of hypertensive, thyroid, thalassemia, or renal diseases. Serum T3, T4, and TSH were estimated utilizing AccuBind ELISA Microwells (sandwich enzyme immune-assay kits) (Monobind Inc., USA). Serum OC, SOST, and OPG were estimated by the use of ELISA kits (SUNLONG BIOTECH, China).

Statistical analysis. Statistical analysis for this study depended upon employing a statistical program (SPSS, version 25). The $P$-value $<0.05$ was regarded as a significant statistical level.

\section{Results and Discussion}

The mean \pm SD of thyroid hormones levels were $\mathrm{T} 3=5.38 \pm 2.23 \mathrm{ng} / \mathrm{ml}, \mathrm{T} 4=21.31 \pm 2.49 \mathrm{ug} /$ $\mathrm{dl}$ and TSH $=0.71 \pm 0.4 \mathrm{IU} / \mathrm{ml}$ in patients with hyperthyroidism, but for hypothyroidism patients were $\mathrm{T} 3=0.62 \pm 0.47 \mathrm{ng} / \mathrm{ml}, \mathrm{T} 4=3.35 \pm 1.21 \mathrm{ug} / \mathrm{dl}$ and $\mathrm{TSH}=42.62 \pm 25.64 \mathrm{IU} / \mathrm{ml}$ while in normal subjects were $\mathrm{T} 3=1.50 \pm 0.28 \mathrm{ng} / \mathrm{ml}, \mathrm{T} 4=9.37 \pm 1.49 \mathrm{ug} / \mathrm{dl}$ and $\mathrm{TSH}=2.11 \pm 0.58 \mathrm{IU} / \mathrm{ml}$.

Serum OC in hyperthyroidism patients was $2.59 \pm 0.63 \mathrm{pg} / \mathrm{ml}$, but for hypothyroidism patients was $3.74 \pm 2.13 \mathrm{pg} / \mathrm{ml}$ while in normal subjects was $4.0 \pm 1.9 \mathrm{pg} / \mathrm{ml}$. SOST level was $23.28 \pm 6.75 \mathrm{ng} /$ $\mathrm{ml}$ in hyperthyroidism, but for hypothyroidism patients was $40.75 \pm 26.71 \mathrm{ng} / \mathrm{ml}$ while in normal subjects was $22.6 \pm 5.0 \mathrm{ng} / \mathrm{ml}$. OPG level in hyperthyroidism patients was $77.24 \pm 14.98 \mathrm{pg} / \mathrm{dl}$ but for hypothyroidism patients was $148.14 \pm 83.01 \mathrm{pg} / \mathrm{dl}$ while in normal subjects was $160.7 \pm 103.4 \mathrm{pg} / \mathrm{dl}$.

The current study revealed that the levels of T3 and T4 were highly significant difference $(P \leq 0.01)$ and SOST with no significant difference $(P>0.05)$ in hyperthyroidism individuals compared to control group, while the levels of OPG and TSH with highly significant difference $(P \leq 0.01)$ and $\mathrm{OC}$ with significant difference $(P \leq 0.05)$ were low. On contrary, levels of T3 and T4 with highly significant difference $(P \leq 0.01)$ and $\mathrm{OC}$ and OPG with no significant difference $(P>0.05)$ in hypothyroidism individuals compared to control group, but TSH level was a highly significant difference $(P \leq 0.01)$ and SOST with significant difference $(P \leq 0.05)$ were increased.

Thyroid hormones play a key role in regulation of the skeletal system development and growth, which causes stimulation of bone formation and resorption leading to thinning of mineralized bone tissues [14]. Previous studies mentioned that thyroid hormones $[15,16]$ and SOST were effective on bone turnover through $\mathrm{Wnt} / \beta$-catenin signaling pathway [17] .

Osteocalcin synthesis occurs at mature osteoblast and hypertrophic chondrocyte cells. Regrettably, OC cellular situations are not only at mineralized surfaces but may both osteocalcin mRNA with proteins are synthesized and produced at bone marrow megakaryocytes, bone marrow adipocytes, and peripheral blood platelet cells. The releasing of immune-active OC fragments into bloodstream is usually associated to bone resorption. The majority of the OC is reserved at extracellular bone tissue matrix, whereas serum OC is the non-absorbed portion of overall OC with hydroxyapatite [18].

Recent reports pointed to a clue that the RANKL/RANK/OPG system could be an important factor connecting both thyroid gland activity and bone metabolic status. The suggestion of thyroid gland regarded as a source or origin of RANKL/ OPG formation is still unknown. However, both mRNA expression and immunochemical reports demonstrated that RANKL/OPG is mainly expressed in benign and malignant thyroid tissue cells [19]. Some immune cells can produce and interact with those mediators. For instance, dendritic cells that express the RANK/RANKL pathway which causing the regulation of special interactions between these dendritic cells and T cells to play an essential role in thyroid gland autoimmunity [20].

Conclusions. Osteoprotegerin and osteocalcin were decreased in thyroid disease individuals compared to control. While sclerostin in thyroid disease individuals is increased compared to control. All studied bone biomarkers were lower in hyperthyroidism rather than hypothyroidism; therefore, thyroid hormone disturbances proved to affect the bone tissue metabolism. The roles of osteoprotegerin, sclerostin, and osteocalcin are newly discovered to be correlated with thyroid disorders which reflect the novelty of the findings of this study.

Conflict of interest. Authors have completed the Unified Conflicts of Interest form at http://ukrbiochemjournal.org/wp-content/uploads/2018/12/ coi_disclosure.pdf and declare no conflict of interest.

Funding. The authors declare this study is an academic article under the supervision of the Ministry of Higher Education and Scientific Research and has not been supported by any Grant. 
Acknowledgments. The authors are grateful to all doctors and health workers at the Clinical Biochemistry Unit of Salah Aldeen General Hospital for their magnificent assistance and unlimited support in order to carry out this research successfully.

РІВНІ ОСТЕОПРОТЕГЕРИНУ,
СКЛЕРОСТИНУ ТА
ОСТЕОКАЛЬЦИНУ В
СИРОВАТЦ КРОВІ ПАЦІЕНТІВ
ІЗ ЗАХВОРЮВАННЯМИ
ЩИТОПОДІБНОЇ ЗАЛОЗИ

F. F. Rija', S. Z. Hussein ${ }^{2 凶}$, M. A. Abdalla

${ }^{1}$ Department of Biology, Tikrit University College of Sciences, Tikrit, Iraq;

${ }^{2}$ Clinical Biochemistry Unit, Salah Aldeen Health Directorate, Tikrit, Iraq;

${ }^{3}$ Department of Human Anatomy, Tikrit

University College of Medicine, Tikrit, Iraq;

凶e-mail: drmohammadahmad68@gmail.com

Підтримання гомеостазу тиреоїдних гормонів відіграє важливу роль в регуляції розвитку скелетної системи, мінералізації кісткової тканини та запобігає ризику переломів. Метою дослідження було оцінити рівні остеопротегерину (OPG), склеростину (SOST) і остеокальцину (OC) в сироватці крові пацієнтів із гіпо- та гіпертиреозом. Було обстежено 90 осіб, з яких 30 здорових становили контрольну групу, 30 пацієнтів із гіпотиреозом і 30 пацієнтів із гіпертиреозом. Проаналізовано рівні OPG, SOST, OC, тиреоїд-стимулювального гормону (TSH), загального трийодтироніну (T3) і загального тироксину (Т4) у сироватці крові. Пацієнти з гіпертиреозом мали високі рівні SOST, T3 і T4 і низькі рівні OPG, OC та TSH порівняно $з$ показниками контрольної групи. У той самий час у пацієнтів із гіпотиреозом були підвищені тільки рівні SOST i TSH, а рівні OPG, OC, T3 і T4 були низькими відносно контрольної групи. Одержані дані вказують на взаємозв'язок рівнів остеопротегерину, склеростину і остеокальцину з порушеннями секреції гормонів щитоподібної залози.

К л ю ч о в і с ло в а: остеокальцин, остеопротегерин, склеростин, захворювання щитоподібної залози.

\section{References}

1. Gogakos AI, Duncan Bassett JH, Williams GR. Thyroid and bone. Arch Biochem Biophys. 2010; 503(1): 129-136.

2. Bianco AC, Salvatore D, Gereben B, Berry MJ, Larsen PR. Biochemistry, cellular and molecular biology, and physiological roles of the iodothyronine selenodeiodinases. Endocr Rev. 2002; 23(1): 38-89.

3. Abe E, Marians RC, Yu W, Wu XB, Ando T, Li Y, Iqbal J, Eldeiry L, Rajendren G, Blair HC, Davies TF, Zaidi M. TSH is a negative regulator of skeletal remodeling. Cell. 2003; 115(2): 151162.

4. Hussein SZ, Ali SJ. Evaluation of Serum Thyroid Hormones and Cortisol Level in Patients with Chronic Renal Failure. 1st scientific conference of medical group colleges 26-27 March 2013; 3237.

5. Hussein SZ, Farhan AS. Ferritin Level in Thyroid Diseases. 1st scientific conference of medical group colleges 26-27 March 2013; 21-25.

6. Davies TF, Ando T, Lin RY, Tomer Y, Latif R. Thyrotropin receptor-associated diseases: from adenomata to Graves disease. J Clin Invest. 2005; 115(8): 1972-1983.

7. Lin C, Jiang X, Dai Z, Guo X, Weng T, Wang J, Li Y, Feng G, Gao X, He L. Sclerostin mediates bone response to mechanical unloading through antagonizing Wnt/beta-catenin signaling. $J$ Bone Miner Res. 2009; 24(10): 1651-1661.

8. Sarıtekin İ, Açıkgöz Ş, Bayraktaroğlu T, Kuzu F, Can M, Güven B, Mungan G, Büyükuysal Ç, Sarıkaya S. Sclerostin and bone metabolism markers in hyperthyroidism before treatment and interrelations between them. Acta Biochim Pol. 2017; 64(4): 597-602.

9. Rija FF, Almahdawi ZM, Hussein SZ. Evaluation of Bone Metabolism Biomarkers in Hemodialysis Chronic Kidney Disease. Indian $J$ Public Health Res Dev. 2019; 10(4): 1660-1665.

10. Hofbauer LC, Heufelder AE. Role of receptor activator of nuclear factor-kappaB ligand and osteoprotegerin in bone cell biology. $\mathrm{J} \mathrm{Mol} \mathrm{Med}$ (Berl). 2001; 79(5-6): 243-253.

11. Bekker PJ, Holloway D, Nakanishi A, Arrighi M, Leese PT, Dunstan CR. The effect of a single dose of osteoprotegerin in postmenopausal women. J Bone Miner Res. 2001; 16(2): 348-360. 
12. Amato G, Mazziotti G, Sorvillo F, Piscopo M, Lalli E, Biondi B, Iorio S, Molinari A, Giustina A, Carella C. High serum osteoprotegerin levels in patients with hyperthyroidism: effect of medical treatment. Bone. 2004; 35(3): 785-791.

13. Zhong N, Xu B, Cui R, Xu M, Su J, Zhang Z, Liu Y, Li L, Sheng C, Sheng H, Qu S. Positive Correlation between Serum Osteocalcin and Testosterone in Male Hyperthyroidism Patients with High Bone Turnover. Exp Clin Endocrinol Diabetes. 2016; 124(7): 452-456.

14. Rija FF, Almahdawi ZM, Hussein SZ. Correlation between Calcium Sensing Receptor with other Calcium Regulators in Osteoporosis and Osteomalacia Patients. Plant Arch. 2019; 19(1): 1199-1207.

15. O'Shea PJ, Kim DW, Logan JG, Davis S, Walker RL, Meltzer PS, Cheng SY, Williams GR. Advanced bone formation in mice with a dominant-negative mutation in the thyroid hormone receptor $\beta$ gene due to activation of Wnt $/ \beta$-catenin protein signaling. $J$ Biol Chem. 2012; 287(21): 17812-17822.
16. Tsourdi E, Rijntjes E, Köhrle J, Hofbauer LC, Rauner M. Hyperthyroidism and hypothyroidism in male mice and their effects on bone mass, bone turnover, and the Wnt inhibitors sclerostin and dickkopf-1. Endocrinology. 2015; 156(10): 3517-3527.

17. Wang L, Shao YY, Ballock RT. Thyroid hormone interacts with the Wnt/beta-catenin signaling pathway in the terminal differentiation of growth plate chondrocytes. J Bone Miner Res. 2007; 22(12): 1988-1995.

18. Lee AJ, Hodges S, Eastell R. Measurement of osteocalcin. Ann Clin Biochem. 2000; 37(Pt 4): 432-446.

19. Heymann MF, Riet A, Le Goff B, Battaglia S, Paineau J, Heymann D. OPG, RANK and RANK ligand expression in thyroid lesions. Regul Pept. 2008; 148(1-3): 46-53.

20. Rija FF, Hussein SZ, Abdalla MA. Physiological and Immunological Disturbance in Rheumatoid Arthritis Patients. Baghdad Sci J. 2021; 18(2): 247-252. 